\title{
IAMJ
}

INTERNATIONAL

AYURVEDIC

MEDICAL JOURNAL

\section{EFFECT OF VAMSHAMULA-KARPURA NASYA IN THE MANAGEMENT OF ARDHAVABHEDAKA (MIGRAINE): A RESEARCH ARTICLE}

\author{
$\underline{\text { Amit Hassan Mazumder }}{ }^{1}, \underline{\text { Kanika Goswami }}^{2}, \underline{\text { Karab Ali }}^{3}$ \\ ${ }^{1}$ PG Scholar, Dept of Samhita and Siddhanta, Govt. Ayurvedic College and Hospital, Guwahati, Assam, India \\ ${ }^{2}$ Asst. Professor, Dept. of Samhita and Siddhanta, Govt. Ayurvedic College and Hospital, Guwahati, Assam, India \\ ${ }^{3}$ Assistant Professor, Dept. of Samhita and Siddhanta, Govt. Ayurvedic College and Hospital, Guwahati, Assam, \\ India
}

Corresponding Author: amithassan959@gmail.com

\section{https://doi.org/10.46607/iamj1309082021}

(Published Online: August 2021)

Open Access

(C) International Ayurvedic Medical Journal, India 2021

Article Received: 23/07//2021 - Peer Reviewed: 02/08/2021 - Accepted for Publication: 07/08/2021

\section{Check for updates}

\begin{abstract}
Ayurveda, the Science of life is an age-old medical system that has always propagated the importance of preventive as well as curative aspects of the diseases. Ardhavabhedaka is one of the Shiroroga(diseases of the head region) which has been correlated with Migraines. Under the umbrella of Headache, Migraine is amongst the world's leading diseases. Ardhavabhedaka comes under the Urdhwajatrugata Vikaras where Nasya has been mentioned as the prime therapy for its management. Acharya Sushruta has mentioned one such Nasya formulation of vamsamula and karpura for its management. Though modern therapeutics has a wide range of drugs for the management of this disease, they are having serious side effects and habit-forming nature. Therefore, there is a need for a research study to find out the efficacy of this herbal Nasya formulation consisting of Vamsamula and Karpura for management of Ardhavbhedaka via Clinical intervention. After the clinical trial, it was observed that there was a highly significant improvement in clinical manifestations of Ardhavabhedaka (migraine).
\end{abstract}

Keywords: Ardhavabhedaka, Migraine, Nasya, Vamshamoola, Karpura. 


\section{INTRODUCTION}

Ardhavbhedaka as one of the shiroroga has been correlated with Migraines, WHO ranks migraines among the World's most disabling medical illnesses because of their underdiagnosed and undertreated in the medical field. Ardhavabhedaka is considered as the perforating or bursting out like pain in one half of the head either right or left ${ }^{1}$. It has been mentioned differently as per the different Acharyas, Acharya Sushruta mentioned it as severe tearing and pricking pain in the half of the head along with giddiness suddenly after a fortnight or ten days caused by all the three $d o s h a^{2}$. Acharya Vagbhatta stated Ardhavabhedaka as the Pain in half side of head ${ }^{3}$. And according to Acharya Charaka. Ardhavbhedaka is caused due to the involvement of the Vata either alone or in combination with Kapha, which seizes one half of the head and causes pain in the sides of the neck, eyebrow, temple, ear, eye or forehead of one side ${ }^{4}$.
The pathogenesis process or Samprapti mentioned according to acharya Charaka states that the Nidana factors like Aharaja (dietary habits), Vihara (vegadharan), Manasika (psychological factors) and Agantuja (external factors like any Aghata to the Shirah) vitiate either Vata alone or Vata along with kapha, these vitiated Doshas further enters the siras of the Shiras, Vitiates the Rakta dhatu, invades the half portion of the head and causes Ardhvabhedaka ${ }^{5}$. There are various formulations and therapy mentioned according to the Acharyas for Ardhavabhedaka, Nasya being one of the important treatment modalities. Acharya Sushruta has mentioned one such Nasya preparation of vamsamula extract and karpura in Uttaratantra $26^{\text {th }}$ Chapter, Shiroroga Pratishedha Adhyaya for the management of Ardhavabhedaka.

Table 1: Description of Vamshamoola \& Karpura:

\begin{tabular}{|l|l|l|}
\hline Description & Vamshamoola $^{6}$ & Karpura $^{\mathbf{7}}$ (Niryasa-extract) \\
\hline Botanical name & Bambusa arundinacea & Cinnamomum Camphora \\
\hline Family & Poaceae & Lauraceae \\
\hline Rasa & Madhura, Kashaya & Tikta, Katu, Madhura \\
\hline Guna & Laghu, Ruksha, Tikshna & Laghu, Rooksha \\
\hline Vipaka & Madhura & Katu \\
\hline Veerya & Sheeta & Sheeta \\
\hline Vamshamoola, doshaghnata & kaphapittashamaka. & Kapha and Pitta Dosha \\
\hline
\end{tabular}

Migraine is one of the leading diseases in today's world coming under the umbrella of Headache. It is underdiagnosed and undertreated. Therefore, there is a need to investigate the effect of the body friendly Ayurvedic compounds mentioned in the classics via clinical intervention. Vamshamoola Karpura Nasya was selected for the present study which was mentioned in Uttara Tantra of Sushruta Samhita for the treatment of Ardhavabhedaka based on various assessment criteria to result in safe, effective, and economic treatment modality.

AIM AND OBJECTIVES: To assess the effect of Vamsamula Karpura Nasya in the management of Ardhavabhedaka (migraine).

\section{MATERIAL AND METHOD:}

Following materials and methods were adopted for conducting the present research study:

\section{Study Centre -}

- $\quad$ Drug Testing Laboratory, Govt. Ayurvedic College \& Hospital, Guwahati- Standardization of the drug

- $\quad$ IPD and OPD, Government Ayurvedic College \& Hospital, Guwahati - clinical study.

2. Selection of Cases/ Patient: A total of 30 patients with features of Migraine have been registered from the OPD of Govt. Ayurvedic College \& Hospital, Jalukbari, Guwahati-14. 
3. Study design: It was an Open Clinical Trial (without a control group) conducted on 30 patients with features of migraines.

4. Preparation of the formulation: The raw drugs have been collected from the local area and market. The trial medicine was prepared at state Ayurvedic pharmacy, Govt. Ayurvedic College \& Hospital, Guwahati-14. After preparing the medicine, it was tested in the drug testing laboratory of Govt. Ayurvedic College, Guwahati.

5. Dosage: 4 drops in each nostril.

6. Duration of therapy: 21 days ( 7 days therapy, 7 days gap then 7 days therapy)

7. Inclusion criteria: Both male and female patients of age between 15-50 years having the signs \& symptoms of Ardhavabhedaka (migraine).

8. Exclusion criteria: Patients having sinusitis, secondary headache caused by meningitis, brain tumour, encephalitis, cervical spondylitis and refractive errors.

9. Criteria for withdrawal: Aggravation of the disease any other serious complications requiring changes in treatment during the trial period.

10. Assessment criteria: based on relief in the signs and symptoms by using a proper scoring pattern.

A. The severity of headache:

- $0=$ No headache

- 1 = Mild headache, patient is aware only if he/she pays attention to it.

- 2 = Moderate headache, can ignore at times

- 3 = Severe headache, cannot ignore but he/she can do his/her usual activities.

- 4 = Excruciating headache, cannot do anything

B. Frequency of headache: Assessed in terms of frequency in days

- $0=$ Nil

- $1=\geq 20$ days.

- $2=15$ days

- $3=10$ days

- $4=\leq 5$ days

C. Duration of headache: Assessed in terms of hours per day.

- $0=$ Nil

- $1=1-3$ hours/day
- $2=3-6$ hours/day

- $3=6-12$ hours/day

- $4=>12$ hours/day

D. Nausea:

- $0=$ Nil

- $1=$ Occasionally

- 2 = Moderate, but doesn't disturb the routine work

- $3=$ Severe, disturbing routine work.

- 4 = Severe enough, small amount of fluid regurgitating from mouth.

E. Vomiting

- $0=$ Nil

- $1=$ Only if headache does not subside

- $2=1-2$ times/day

- $3=2-3$ times/day

- $4=$ Forced to take medicine to stop vomiting.

F. Methodology of therapy: Nasya Administration - It involves the following three steps:

Purva karma:

Preparation of the nasya Aushadhi: The liquid form of Aushadhi was made by mixing the powder of Vamshamoola (since the fresh bamboo root were too dry to be made into Swaras form) and Karpura in the ratio of 4:1 with water (quantity sufficient) and kept for 30 mins after which it was filtered. The drugs were measured accurately using an analytical balance. Following measured quantity of the compound was taken as per the sufficiency to be administered to one patient:
a) Vamshamoola Choorna : 500mg
b) Karpura : 125mg
c) Water: Q.S (Quantity Sufficient)
- $\quad$ Preparation of the patient

a) Snehana Karma: Shiroabhyanga with Mahabhringraj taila was done.

b) Swedana Karma: Mild Swedan was done by Pani- Tapa Sweda.

Pradhana karma: The patient was made to lie down in a supine position. After lowering the patient's head, the tip of the nose was raised and the Aushadhi was instilled in both the nostrils - 4 drops/nostril.

Paschat karma: Mukha Abhyanga (facial massage) and feet, shoulders, palm and ears were massaged, and 
the patient was made to lie in the supine position (Uttana) for about 2 minutes. The face and neck were again subjected to sudation (Pani- Tapa Sweda). To avoid swallowing Nasya Aushadhi, the patients were asked to spit out the excessive Nasya Ausadha.
RESULT: Based upon the obtained findings, followed by statistical analysis which was carried out using appropriate statistical tools such as arithmetic mean, percentage, standard deviation etc. following result and interpretation can be drawn:

Table 2: The overall effect of therapy on headache (By paired t-test):

\begin{tabular}{|l|l|l|l|l|l|l|l|l|}
\hline \multirow{2}{*}{$\begin{array}{l}\text { Headache } \\
(\mathrm{n}=30)\end{array}$} & \multicolumn{2}{|l|}{ Mean score } & Mean differ- & percentage & \multicolumn{2}{l|}{ S. D } & t value & p-value \\
\cline { 2 - 7 } & BT & AT & ence & & BT & AT & & \\
\hline Intensity & 1.87 & 1.13 & 0.74 & $39.60 \%$ & 0.68 & 0.51 & 8.93 & $<0.01$ \\
\hline Frequency & 1.93 & 1.3 & 0.63 & $32.64 \%$ & 0.58 & 0.47 & 5.64 & $<0.01$ \\
\hline Duration & 2.03 & 1.27 & 0.76 & $37.43 \%$ & 0.67 & 0.45 & 6.71 & $<0.01$ \\
\hline
\end{tabular}

Regarding the effect of therapy on headache statistically highly significant $(\mathrm{p}<0.01)$ result was found. Improvement in intensity (39.60\%), frequency (32.64\%), and duration $(37.43 \%)$ were also found.

Table 3: Overall effect of therapy on Nausea and vomiting

\begin{tabular}{|l|l|l|l|l|l|l|l|l|}
\hline \multirow{2}{*}{ Other symptoms $(\mathrm{n}=30)$} & \multicolumn{2}{|l|}{ Mean score } & \multirow{2}{*}{ Mean difference } & \multirow{2}{*}{ percentage } & \multicolumn{2}{|c|}{ S. D } & t value & \multirow{2}{*}{ p-value } \\
\cline { 2 - 10 } & BT & AT & & & BT & AT & & \\
\hline Nausea & 0.5 & 0.1 & 0.4 & $80 \%$ & 0.68 & 0.31 & 3.89 & $<0.01$ \\
\hline Vomiting & 0.27 & 0.067 & 0.2 & $75 \%$ & 0.45 & 0.25 & 2.69 & $<0.01$ \\
\hline
\end{tabular}

Regarding the effect of therapy on Nausea and vomiting, a statistically highly significant $(\mathrm{p}<0.01)$ result was found. It was found that before treatment the mean value of nausea and vomiting was 0.5 and 0.27 respectively, which had reduced to 0.1 and 0.067 respectively.

All these obtained statistical data indicates Vamshamoola - Karpura Nasya therapy resulted in marked improvement in the clinical manifestation of Ardhavabhedaka.

\section{DISCUSSION}

In Ayurvedic literature, Acharvas have described the Shiroroga caused due to the tridosha, among which Ardhavbhedak is one of the most common diseases occurring these days. Ardhavbhedak has been explained as tridosha by Acharya Sushruta, Vata-kaphaja by Charak and Vataja by Acharva Vagbhata affecting the Urdhwanga (head region). Nasya Karma is one of the Shodhana processes, which eliminates the vitiated Doshas of the Urdhvanga. Acharya Sushruta has mentioned one such Nasya preparation of vamsamula extract and karpura in Uttaratantra $26^{\text {th }}$ Chapter,
Shiroroga Pratishedha Adhyaya for the management of Ardhavabhedaka. So, after the clinical trial, it was found that the maximum number of patients were having Shirah-shoola (headache), followed by Hrillas (nausea) and Chardi (vomiting) $40 \%$ and $26.67 \%$ respectively which are identical to the textual Lakshanas (symptoms) of Ardhavabhedaka (migraine). The intensity of headache was moderate in maximum patients $(53.33 \%), 56.67 \%$ with the duration of 3-6 hours. Statistical Analysis regarding the effect of therapy on headache based on intensity, duration and frequency showed a highly significant $(\mathrm{p}<0.01)$ result.

Mode of action of the Drugs: In Ardhavabhedaka samprapti, it is told that Vata alone or along with Kapha dosha dislodged in shiras cause the disease and few authors consider it as Tridoshaja also. Based on the following factors the possible mode of action of these drugs can be explained:

- Based on Rasas - Vamsha has Madhura and Kashaya rasa and karpur have taken, katu and Madhura rasa. Both the drugs predominantly contain rasas which help in pacifying Vata and kapha dosha. 
- Based on Vipaka - Vipaka of Vamsha is Madhura and karpura is katu. Understanding the samprapti of the disease Ardhavbhedaka, Vata is associated with kapha, here Madhura vipaka will act on vata dosha and katu vipaka on kapha respectively.

- Based on gunas: Both the drugs have Laghu, Rooksha, Teekshna gunas which are useful in Kapha - Vataja condition. Furthermore, Vamsa has laghu, ruksha and tikshna guna and karpura also possesses laghu and ruksha guna. Laghu Guna and Tikshna Guna have Sroto-shodhaka property, which helps in expelling the morbid doshas.

- Based on Doshaghnata: Different parts of bamboo have different doshaghnata few known for pacifying Vata dosa also, Vamshamoola specifically is mentioned as kaphapitta shamaka, and Karpura is also mentioned as kaphapitta shamaka. Ardhavabhedaka according to Sushruta is caused due by all the tridosha. hence, these drugs will pacify all the tridosha and relieve Ardhavabhedaka.

\section{CONCLUSION}

Ardhavabhedaka (Migraine) is one of the leading most diseases in the world caused due to the tridoshas in the Urdhwanga, there is various treatment modality mentioned as per the Acharyas, Nasya being one of the most important therapy. The reference of Vamshamoola Karpura Nasya in Ardhavbhedaka according to Sushruta when subjected to clinical trial showed the statistically significant result, the patient had a marked improvement in their symptoms after receiving the therapy. Thus, indicating that the chosen Nasya formulation holds to the hypothesis in the management of Ardhavabhedaka (Migraine).

\section{REFERENCES}

1. Sharma AR. Sushruta. Sushruta Samhita. Sutrasthanam Chapter. 21 verse 5. Varanasi. Chaukhamba Surbharati Prakashana, 2009; pg. no. 177.

2. Shastri A. Sushruta. Sushruta Samhita. Uttartantra, Chapter 25. Verse 15. Varanasi. Chaukhamba Sanskrit sansthana, 2010, pg. no.166.
3. Tripathi B. Vagbhata. Astangahrdayam, Sutrashtana, Chapter 23. Verse 7-8. Delhi Chaukhamba Sanskrit Pratishthan Prakashana, 2009, pg. no. 726.

4. Pandey K, Chaturvedi G. Agnivesha. Charaka Samhita, siddhisthana Chapter 9. Verse 74-78, Varanasi Chukhamba Bharti Prakashan, 2009; Uttrardha, pg. no. 1060 .

5. Tripathi R. Agnivesha Charak Samhita (Vol. 2). Sutrasthana, Chapter 27. Chaukhamba Sanskrit Pratishthan, Varanasi, 2009.

6. Chandra K, Chaudhari BG, Dhar BP et al, Database on medicinal plants used in Ayurveda. Vol 8. CCRAS, New Delhi, 2007, pg. no. 560.

7. Pandey GS. Bhavprakash Nighantu, Chaukhamba Bharati Academy, Varanasi, 1998, page no. 175 to 178.

\section{Source of Support: Nil \\ Conflict of Interest: None Declared}

How to cite this URL: Amit Hassan Mazumder et al: Effect Of Vamshamula-Karpura Nasya In The Management Of Ardhavabhedaka (Migraine): A Research Article. International Ayurvedic Medical Journal \{online\} 2021 \{cited August 2021\} Available from: http://www.iamj.in/posts/images/upload/1683_1687.pdf 